\title{
How do you define a family lawyer? ${ }^{1}$
}

\author{
Christine Piper \\ Brunel University
}

This is a foolhardy, if not downright foolish, title. It is not an original question and there are, consequently, many weighty and much quoted 'answers' in academic texts. ${ }^{2}$ In addition, as our current Lord Chancellor pointed out, there is no shortage of potential critics: 'When it comes to family law we all think that our views are as good as those of anyone else'. ${ }^{3}$ However, my focus is not family law as such but practitioner, rather than academic, family lawyers though there may be implications for teachers of future legal professionals. My starting point is the contention of Judge Nigel Fricker that 'Family law and adjudication are conceptually different from most other areas of law' ${ }^{4}$ Such a contention clearly assumes there is a standard model of lawyering from which family law deviates. This may or may not be so. ${ }^{5}$ The focus of this article is not to critique models of

1. An earlier version of this article was presented as a paper at the SPTL Conference, Family Law Section, Manchester University, 9 Sept 1998. I am grateful for all the helpful comments made to me on that occasion, and for the suggestions made by my colleagues in the Centre for the Study of Law, the Child and the Family at Brunel University and by the journal's anonymous referees.

2. M Freeman 'Towards a Critical Theory of Family Law' (1985) 38 Current Legal Problems 153-185; B Hoggett 'Private Lives and Public Duties, What is Family law For?' The Eighth ESCR Annual Lecture 23 October 1997; J. Eekelaar 'What is “Critical” Family Law?' (1989)108 LQR 244; K O’Donovan Family Law Matters (London: Pluto Press, 1993); J Dewar 'The Normal Chaos of Family Law' (1998) 61 (4) MLR 467-485. 3. Lord Irvine of Lairg, Hansard, Lords, 11 Dec 1996, 1095, in a debate on the role of the family.

4. Judge Nigel Fricker 'Family Law is Different' (1995) 33(4) Family and Conciliation Courts Review 403-414 at 403.

5. Fricker, concentrating on the judiciary, argues that family law is different because the judge must make a choice, 'that belongs to the parties', about the future needs of the family. For him, the standard model is where a judge deals with past events on the basis 
practice developed from empirical studies of 'lawyering' ${ }^{6}$ but, rather, the perceptions of practising family lawyers and those who regulate the legal profession about the existence and nature of the 'difference' which Fricker claims. Evidence of a belief in this difference is the development, within the legal profession, towards the accreditation of specialist family and, particularly, child lawyers.

\section{CERTIFIED SPECIALISTS}

The claims of practitioners that family law is a specialist body of law is a relatively recently development, ${ }^{7}$ yet the 1990s have seen the almost widespread acceptance of the idea that legal professionals working with family law should be specialists. The main impetus came from the passing of the Children Act 1989 and the importance of specialist training for those working with that Act was a common theme through all the annual reports of the Children Act Advisory Committee, ${ }^{8}$ the first two reports being concerned with the establishment of a 'specialist cadre' of judges, ${ }^{9}$ the later reports turning their

of legal rights (above n 4 at 404). There has, however, been considerable change in the organisation and practice of lawyers in the last two decades (see P Thomas 'Thatcher's Will' (1992) 19(1) Journal of Law and Society 1-12). Hanlon, for example, has argued that 'the idea of a unified and homogeneous solicitors profession is past its sell by date' (G Hanlon 'A Profession in Transition? - Lawyers, The Market and Significant Others' (1997) 60 Modern Law Review 798-822 at 822.

6. For a review of several such studies relating to divorce lawyers see $\mathrm{C}$ Piper 'Norms and Negotiation in Mediation and Divorce' in M Freeman (ed) Divorce: Where Next? (Aldershot: Dartmouth, 1996) 68-72.

7. See F Bawdon 'In the Family Way' (1995) Solicitors Gazette 22 February, 8, at 31. Family law as a specialist academic subject is also a relatively recent development, its birth being located in the 1960s: see S Jolly 'Family Law' in P Thomas (ed) Socio-Legal Studies (Aldershot: Dartmouth,1997); M Freeman 'Family Values and Family Justice' (1997) 50 Current Legal Problems 315-359.

8. Now subsumed in the Advisory Board on Family Law.

9. Children Act Advisory Committee Annual Report 1992/3 (London: Lord Chancellor's Department, 1993) p 80. See also Annual Report 1991/2 (London: Lord Chancellor's Department, 1992) p 20. 
attention to magistrates, barristers and solicitors. ${ }^{10}$ Solicitors acting in public law proceedings on behalf of children are now usually members of the Children Panel, there is a thriving Association of Lawyers for Children and the Legal Aid Board's franchising of firms for family law work is expected to encourage further specialisation. ${ }^{11}$

By the time of the Children Act Advisory Committee's Final Report, the clear message $^{12}$ was that all lawyers engaged in private law and public law family cases should have 'appropriate knowledge, experience and personal qualities'. ${ }^{13}$ The Council of the Law Society has absorbed the message and outlined a system of accreditation for family lawyers, planning to publish a list of such specialists by early 1999. ${ }^{14}$ The Bar Council has not yet developed such a scheme ${ }^{15}$ though, together with the Law Society, it has been asked by the Chairman of the Advisory Board on Family Law to supply information about progress towards ensuring training and accreditation in Children Act cases. ${ }^{16}$

It would appear that a large proportion of the legal profession now believes that practising family law is a specialism which should be practised only by specialists. What the specialism consists of has not been a bone of contention - the issues have been whether or not further training is required and whether the specialist needs a piece of paper to prove specialist status. The accreditors and the accredited have, it seems, a shared vision of

10. See Children Act Advisory Committee Annual Report 1993/4 (London: Lord Chancellor's Department, 1994) pp 47-50.

11. 'Standards of advice and advocacy in Children Act cases should, in any event, be improved by the development of the ... franchising scheme, which aims to provide a quality assured service by solicitors' (Children Act Advisory Committee Annual Report 1996-7 (London: Lord Chancellor's Department, 1997) p 17.

12. A message also given in its Annual Reports for 1993-4 (above n 10 at p 34) and 1994-5 (London: Lord Chancellor’s Department, 1995, at pp 31-2).

13. Above $\mathrm{n} 11$ at $\mathrm{p} 18$.

14. See Family Law Panel: Procedural Notes (London:Law Society, 1998).

15. See, for example, The Children Act Advisory Committee (above n 11) pp 16-17.

16. Advisory Board on Family Law 1st Annual Report 1997-8 (London: Lord Chancellor's Department, 1998) at p 19. 
what a good specialist family lawyer is and does. If that is so, it is in contrast to the position in academia where family lawyers are generally content to live with varied and often conflicting conceptual and theoretical perspectives about the function, nature and influence of law in relation to the family. ${ }^{17}$ Indeed, the great variety of family law syllabi on offer ${ }^{18}$ would suggest that law graduates may hold different ideas about what constitutes family and child law. ${ }^{19}$

In Law Schools and in professional literature, however, it is possible to discern an increasing importance of law and practice relating to children. Much of the guidance for family practitioners concentrates on issues relating to children; indeed some of it conflates 'family' with 'child-related' law. ${ }^{20}$ In relation to litigation this is probably justified. ${ }^{21}$ Parts IV and V of this article will also concentrate on lawyers' approaches when their clients are parents, questioning at the end whether the conclusions are valid for wider family work. The focus will be on how practising family lawers explain and work with their 'specialness'. 22

17. See, for example, Dewar's review of the more important theoretical approaches (above $n$ 2).

18. I am grateful to Jacqueline Priest for making available to me the research completed for the Family Law Section of the SPTL which shows how modularisation has often led to there being more than one module about family law on offer to students. Many of the divisions of material made are somewhat artificial: some are labelled Family Law I and II, some are separate child law modules, others have more imaginative titles. Such changes have, I would argue, also intensified the trend to a more child-related family law. 19. Though the titles and coverage of modules helps create a concept of what family law is these are often determined less by theoretical and pedagogical discussion than by factors such as staff availability, the number of hours and credits allowed for a module and university asessment requirements.

20. The Family Law Act 1996 indicates a similar conflation: many of the provisions in Parts I and II aim to encourage conflict-free divorce and harmonious post-separation parenting and yet are applicable to all divorcing spouses, with or without children.

21. Fricker lists four areas with which 'most' family litigation is concerned, three of these necessarily involve children (above n 4 at p 404).

22. Or, to amend the question posed by Ann Bottomley over a decade ago, 'What is happening to family lawyers?': A Bottomley 'What is Happening to Family Law?' in M 


\section{NOT DIFFERENT AT ALL?}

The literature produced by and for professional lawyers reveals at least five approaches or skills which are portrayed as characteristics of the specialist family lawyer. First, particular forms of 'client care' form part of the transaction criteria to which 'franchised' family solicitors must work, for example the sending of explanatory letters on particular issues and at particular stages. Yet client care is a feature of the franchise requirements for other areas of law and is a prevalent business technique. Similarly, as is suggested by the requirements for admission to the Law Society’s Children Panel as well as by the selection of cases and practice statements reviewed in the Children Act Annual Reports, a particular knowledge about legal procedures, which includes knowledge about confidentiality and access to documents, is deemed necessary. But knowledge of specialist rules of evidence and procedure is to be expected in all branches of law.

Thirdly, the family law specialist is also perceived as a good case manager. The Practice Direction issued by the President of the Family Division in 1995, headed 'Case Management', lists nine sets of expectations for the good family lawyer, which focus on the need for efficiency, avoidance of delay, photocopying in A4 format bundles 'suitably secured' and delivered in good time and the brevity of skeleton arguments. ${ }^{23}$ Yet exhortations to better case management are perfectly in line with Lord Woolf's recommendations for the management of civil disputes generally and reveal, not evidence of specialist lawyering, but evidence of the colonisation of yet another area of public life

Freeman (ed) The State, the Law and the Family, Critical Perspectives (London: Tavistock, 1984).

23. [1995] 1 FLR 456-457. Bundles were also discussed by the Court of Appeal administration Committee of May 1998 and were an issue in Ata $v$ American Express Bank Ltd, The Times June 261998. 
by the management discourse.

Fourthly, what family lawyers have argued is the really special feature of their specialism is that they are not 'tough', litigious or adversarial. The family law specialism ‘requires a gentle approach’ - in contrast to the pre-Solicitors’ Family Law Association (SFLA) days when 'people treated matrimonial as another branch of litigation'24 - and 'particular sensitivity' ${ }^{25}$ This approach was endorsed by the President of the Family Division in his guidance to Family Court Business Committees: '[the adversarial approach] is not appropriate in children's cases ${ }^{26}$ and so the Law Society's proposed criteria for admission to the Family Law Panel include the following, under the heading ‘Approach to Family Law Work':

'Members of the panel are expected to show the necessary sensitivity in dealing with family law clients and not to act in an unduly adversarial manner. A leaflet setting out the aspirational aspects of family law work will be available. ${ }^{27}$

Family lawyers, therefore, see themselves as special because of a different working approach and a different `language’, which has changed 'from “fighting” and "losing”

24.Nigel Shepherd, then chair of the SFLA, quoted in Bawdon, above $\mathrm{n} 7$, at 8 .

25.Fricker, above n 4 pp 403, 406, 412.

26. Above $n$ 11, Annexe A at 21. It has been argued that the change of approach from an adversarial to a conciliatory one has been the legal profession's main response to the challenges to the centrality of lawyers in the divorce process and one in which the SFLA played a major role: see J Walker 'Is There a Future for Divorce Lawyers?' (1996) 10 International Journal of Law, Policy and the Family, 52-73 at 61; B Neale and C Smart, “"Good” and "bad” lawyers? Struggling in the Shadow of the Law' (1997) 19(4) Journal of Social Welfare and Family Law 377-402 at 380. See, further, Conciliation Project Unit Report to the Lord Chancellor on the Cost and Effectiveness of Conciliation in England and Wales (University of Newcastle, 1989) paras 9.24-9.37 and J Walker, P McCarthy and N Timms Mediation:The Making and Remaking of Cooperative Relationships (University of Newcastle: Relate Centre for Family Studies, 1994) p 138. 
legal "battles” to “negotiating” “amicable settlements” and achieving "fair outcomes”, 28

But, again, the value of calm negotiation, the benefits of alternative dispute resolution (ADR) and the avoidance of litigation where the parties wish to, or must have, an on-going relationship, has been well understood in relation to commerce as well as the family, as evidenced, for example, by the existence of CEDR. ${ }^{29}$

These four special characteristics claimed by the family practitioner are characteristics which are not unique to family law: they could be taken to support a claim to specialist status within the practice of any branch of law at the end of the 20th century. There is also another special feature assumed in the professional literature: that the specialist family lawyer must absorb, use and interact with much which is not law. ${ }^{30}$

\section{THE NON-LAW LAWYER}

These non-law elements are apparent in the guidance for family specialists. Sensitive client

27. Above $\mathrm{n} 14$ at $\mathrm{p} 4$.

28. Walker, McCarthy and Timms, above n 26, p 131.

29. Centre For Dispute Resolution, based in London. It is an independent organisation, launched with the support of the Confederation of British Industry to promote ADR techniques and services. However, as Hanlon (above $n$ ) points out, there is now a clear difference of practice between large commercial firms with 'organisational clients' and other commercial law practices.

30. This is not to say that it is only in family law that practitioners require knowledge from other disciplines: the intellectual property lawyer must currently have knowledge about computer software, for example. My point is, rather, that family lawyers give such 'non-law' a very high priority. 
care in relation to children, for example, is related to the psychological needs of the child. The 'Personal Commitment' section of the SFLA Guide to Good Practice for Solicitors Acting for Children states,

'1. ... Each member of the Children Panel must give an undertaking as to the conduct of cases. This undertaking is in the following terms: -

"1. ... I will not normally delegate the preparation, supervision, conduct or preparation of the case ...

3. If it is in the best interests of the child or necessary to obtain another advocate: ... I will obtain an undertaking from that advocate to:-

(a) attend and conduct the matter personally ...."

2. Any solicitor contemplating acting for a child must be prepared to make such a commitment. ... The professional and emotional challenges which these cases present should not be underestimated. ${ }^{, 31}$

The assumption is that the lawyer has knowledge of child psychology so that he or she accepts that the child client needs a more stable relationship with a lawyer than does an adult and that the relationship requires emotional and well as legal input from the lawyer. The child must also not be pressured: 'It is important to proceed at the child's pace and allow the child sufficient "space" and "permission" to change course or ultimately withdraw' ${ }^{32}$ Judge Fricker argues similarly for the focus on needs in relation to the adjudicatory role: 'the critical function of the court is to evaluate the

31. Solicitors' Family Law Association Guide to Good Practice for Solicitors Acting For Children (4th. Edn. 1997), at 3.

32. Above $\mathrm{n} 31$ at 7. 
present and future needs and responsibilities of the several members of the family, ${ }^{33}$

How this evaluation is done has, of course, been extensively theorised. What has been at issue is the influence of the legal and the welfare discourses and the nature of the relationship between them. Theorising from a systems perspective, for example, has focussed on why and to what extent principles and concepts within family law are reconstructions of knowledge from non-law disciplines ${ }^{34}$ or, conversely, whether the 'colonisation' is the other way round. Whatever the theoretical explanation for this interdsciplinarity, family lawyers are now required to be, or at least to represent themselves as being, knowledgeable about the welfare of the child and family dynamics as well as law. The recently devised mission statement of the SFLA education committee embodies these requirements:

- $\quad$ to equip members with the skills, insight, and information necessary for them to apply the [SFLA] code of practice in their family law work;

- $\quad$ to enable members to give legal advice which is enhanced by an understanding of the emotional aspects of family life and the personal consequences which may follow any change;

- $\quad$ to increase members' self-awareness so that their client relationships are well boundaried and creative. ${ }^{35}$

Some of this 'insight' will flow from knowledge of the 'psy-sciences' but as recent research has pointed out, many of these skills are not technical, 'the role demands life

33. Fricker, above n 4, at 404.

34. Examples of such concepts can be found in section 1 of the Children Act 1989: the welfare principle, the no order principle and the idea that delay is prejudicial.

35. See D Wright “'CCode rage” and the Emergency Toolkit’ (1997) 27 Family Law 378, 
skills ${ }^{36}$ - the life experience required, presumably to help develop the 'sensitivity' that is also deemed necessary.

The need for child welfare knowledge and particular personal qualities is linked to what is, in effect, a self denying ordinance for family lawyers that, in the interests of the family, the law and the lawyer must play lesser roles: the family lawyer must instead encourage client 'responsibility'. ${ }^{37}$ Family solicitors are being urged, by their professional bodies and by the judiciary, to put the welfare of the family and child first and stress relationships, responsibilities and the informal resolution of conflict. How far have practising solicitors absorbed these ideas, to what extent do they explain what they do in these terms and how far does practice appear to embody these ideas?

IV THE GOOD FAMILY LAWYER

\section{Research samples}

at 378 .

36. R Bailey-Harris, R Davis, J Barron and J Peara Monitoring Private Law Applications Under the Children Act: Research Report to the Nuffield Foundation (Bristol University, 1998) p 29.

37. Fricker, above n 4 at 404. 
The three most recent pieces of relevant empirical research so far reported are those done by the Centre for Research on Family, Kinship and Childhood at Leeds, the Centre for the Study of Law, the Child and the Family at Brunel University and the Department of Law at Bristol University. Somewhat earlier relevant research is that by the Relate Centre for Family Studies at Newcastle University ${ }^{38}$ and by Gwyn Davis. ${ }^{39}$

The Leeds research used a sample composed of 37 solicitors working in the Yorkshire region, 20 of whom were members of the SFLA, with 20 from large city and 16 from suburban practices. ${ }^{40}$ The Bristol research was undertaken in 1996-7, using observation in 4 county courts in the south-west, visits to 4 other courts, 38 extensive case studies and a study of 345 county court files of section 8 applications made largely in $1994^{41}$

The Brunel sample was of thirty-six solicitors (18 men and 18 women) who were self-classified as family law specialists, ${ }^{42}$ nearly all did mostly private law family work ${ }^{43}$ in firms with at least three partners ${ }^{44}$ and they were chosen from two different court areas. ${ }^{45}$ On average, the solicitors were spending three-quarters of their time on what was

38. For example see Walker, McCarthy and Timms, above n 26.

39. G Davis Partisans and Mediators (Oxford: Clarendon Press, 1988); G Davis, S Cretney and J Collins Simple Quarrels (Oxford: Clarendon Press, 1994). See, also, L Neilson 'Solicitors Contemplate Mediation - Lawyers Perceptions on the Role and Education of Mediators' (1990) 4 International Journal of Law and the Family, 235-269, which was based on an independent study using a postal questionnaire sent to SFLA solicitors in the Greater London area and resulting in responses from 152 solicitors.

40. Neale and Smart, above n 26, p397 n 14.

41.Bailey-Harris, Davis, Barron, Peara, above n 36, Ch. 2.

42. We used the Law Society regional directories to obtain the category of solicitors from which we drew a random sample. Two criteria were that they worked in a firm which had claimed a family law specialism in that publication and that each individual solicitor had listed family as their first or second specialism.

43. Two solicitors found to be doing only care cases were not interviewed.

44. The Law Society Directory of Solicitors and Barristers (1994) suggests that $43 \%$ of firms had 2-4 partners.

45. 'North' and 'South': these were not areas used by the other research projects. 
loosely defined as `matrimonial', that is, all family excluding 'care’ work. ${ }^{46}$ Only five of the solicitors spent less than $50 \%$ of their time on private law work and all but one of them were members of the Children Panel who spent all or most of their remaining time on public law child cases. All of the solicitors interviewed had spent all or most of their professional lives as solicitors on family law work, ${ }^{47} 8$ were trained mediators ( 6 by the FMA and 2 by BALM ${ }^{48}$ ), 11 were on the Children Panel and 27 were members of the SFLA. ${ }^{49}$ All the questions asked of the solicitors related to their practice when advising new divorce clients with children. ${ }^{50}$ Three-quarters of the solicitors worked in firms

46. The amount of time spent on such work by individual solicitors was estimated by them as ranging from $15 \%$ to $100 \%$ of their professional working hours. Interestingly, the Law Society is normally requiring a 'specialist' family lawyer to have notched up only 350 chargeable hours of family law work each year in the 3 years before admission to the Family Law Panel (see Law Society, above n 14 at 3).

47. Thirty of the 36 had spent all the time since qualified doing a significant amount of family work. The period of time since being admitted as a solicitor ranged from 2 - 33 years.

48. British Association of Lawyer Mediators.

49. Only 3 of the 36 solicitors were neither mediators nor members of SFLA and were also not on the Children Panel.

50. 56\% of divorces in 1994 were to couples with children under 16: see J Haskey 'Divorce Statistics' (1996) 26 Family Law 301. 
franchised by the Legal Aid Board for family law work ${ }^{51}$ and many of the questions took into account the transaction criteria imposed for divorce work. ${ }^{52}$

The Newcastle researchers interviewed 21 lawyers (including 18 females) most of whom worked in firms of up to ten partners and all of whom had advised comprehensive mediation clients in relation to 23 cases. Over half had practised for less than 10 years, 13 were members of the SFLA and 5 of the FMA. ${ }^{53}$ The Law Society Study by the Newcastle Centre used a postal questionnaire of FMA members which produced 216 completed questionnaires of which 116 were from lawyers. ${ }^{54}$

\section{The good, the bad and the aggressive}

Despite the picture of divorce solicitors - as adversarial and negotiating only 'at arm's length’ - painted by the Consultation and White Papers which preceded the Family Law Act $1996,{ }^{55}$ the above research suggests solicitors very rarely operate within a legal discourse or in an adversarial manner when dealing with disputes about the children of a marriage. Their working practices are apparently guided by the welfare of the child and family and they reconstruct client's interests in a way which reduce the need to use legal rights and the adversarial system. It would seem that family lawyers have reconciled the

51.Twenty-two were already franchised, 4 others were in firms that were being monitored for a grant of franchise and another was in the process of organising the application.

52. The franchised solicitors were asked, inter alia, what information they both gave and sought, their preferred strategies in relation to contact and residence disputes and what they believed constituted the welfare of the child in the circumstances with which they were dealing. The remaining solicitors were asked similar questions about their practice. 53. Walker, above n 26 at 64-5; Walker, McCarthy and Timms, above $n 26$ at 25.

54. P McCarthy and J Walker 'Involvement of Lawyers in the Mediation Process' (1996) 26 Family Law 154-158.

55. Lord Chancellor's Department, Looking to the Future: Mediation and the Ground for Divorce Cmnd 2424,(London: HMSO, 1993); Lord Chancellor's Department, Looking to the Future: Mediation and the Ground for Divorce Cmnd 2799 (London: HMSO, 1995). 
conflicting imperatives of furthering the client's interests and upholding the welfare of the child and family by allowing 'welfare' to win. According to Smart and Neale, lawyers are deemed as 'bad' if they pursue traditional individualised rights and 'good' if they resolve any conflict of principle in favour of what is taken as the greater good of families, and being 'good' in that sense 'established their credentials as specialists in family law'. ${ }^{56}$ Very few lawyers are 'bad': Neale and Smart's research identified a small number only, Davis' research likewise found only a small group of 'aggressive' solicitors and none of the solicitors interviewed in the Brunel sample could be said to be what Wright has called 'code-breaking' members of the SFLA. ${ }^{57}$ Not all lawyers managed the peak of goodness however: in Smart and Neale's research most were 'flexible' - between good and bad.

What is significant, however, is not that family lawyers are unable to work all the time as 'good' lawyers, but that solicitors appear to have internalised an agreed set of 'rules’ which must be followed by those aspiring to be good family lawyers. This means, according to Michael King, that 'the normative framework within which [solicitors] operate tends then to go far beyond the general principles of law established by precedent to include a distillation of the knowledge established by child welfare experts and their research studies'. ${ }^{58}$ Bailey-Harris et al also conclude that, in relation to the court process for section 8 applications, 'the process of adaptation which we have described can make practitioners' core disciplines seem relatively unimportant’ [emphasis in the original]. ${ }^{59}$

'In the absence of legal rules, other than procedural rules, disputes tend to be settled by

56. Neale and Smart, above $\mathrm{n} 26$ at 337-8, 380.

57. Respectively, Neale and Smart above n 26, Davis above n 39, Wright above n 35 at 358.

58. M King 'Being Sensible: Images and Practices of the New Family Lawyer' (1999, forthcoming) Journal of Social Policy. 
reference to norms. These are not in essence legal norms other than in the limited sense that they are employed within a legal context. Legal knowledge is hardly relevant. It is essentially 'welfare’ discourse expressed as legal principle.' 60

The welfare discourse, with its emphasis on the benefits of parental cooperation and the child's contact with both parents, also enables solicitors not only to label themselves as good or bad but also the parents who are their clients. 'Good' parents are those who agree outcomes with their spouse, do not want to make applications to court and allow contact to the other parent. These parents are therefore taking the sensible approach to divorce: those parents who refuse to cooperate and wish to use the courts are unreasonable. ${ }^{61}$ The following response from a solicitor interviewed for the Leeds research illustrates this:

'The only time I lay down the law and I'm heavy handed is if I've got a mother who's not allowing contact ... I try to beat everybody into submission. ... The prospect of a court ever backing [a contact order] up with [committal proceedings] is very unlikely, but I would never tell the mum that. ... . I've got a particularly difficult case at the moment where the mother [the client] has ... been subject to what seems to be some nasty incidences of violence and fled the area specifically to get away.... Now persuading her to get contact up and running again is very, very difficult. And in fact we [the two lawyers] were able to arrange that. ... It's a question of building up mutual trust again.' (S.H. Male, SFLA [solicitor]). ${ }^{62}$

59. Bailey Harris, Davis, Barron and Peara, above n 36 at 28.

60. Above n 36 at 27.

61. King, above $n 58$.

62. Neale and Smart, above n 26 at 392. Such solicitor 'negotiations', as the Bristol researchers $\mathrm{n}$, 'creates an impression of solicitors acting in concert in the face of one (or 
So do we just define family lawyers as rather odd and expensive social workers, ${ }^{63}$ particularly nice people or lawyer-psychologists? Any of these definitions, I suggest, are somewhat simplistic and hide professional angst. The practitioner culture is one 'of considerable subtlety and sophistication'. ${ }^{64}$ Family lawyers have been trained as lawyers and are Solicitors of the Supreme Court with professional presumptions about forwarding the interests of the client and about the importance of legal rights and remedies. They are also in business and need clients: they must simultaneously convince clients that 'litigation is likely to do more harm than good to their children and on the other hand that the law is able to help out in the case of an unreasonable parent and that this help will eventually be of benefit to the child ${ }^{, 65}$ and that they know when to move from the non-use of law to the use of law. It is not surprising that all three of the recent research projects discussed above concluded that being a family lawyer is 'primarily about client handling' ${ }^{66}$ Furthermore, the way that family lawyers handle clients - such that these tensions are resolved or bypassed - is unique to the practice of family law.

V RHETORICAL STRATEGIES

two) difficult parents' see Bailey-Harris, Davis, Barron and Peara, above n 36 at 29. 63.Bailey-Harris, Davis, Barron and Peara, above n 36 at 28.

64. Davis, Cretney and Collins, above n 39 at 259.

65. King, above n 58 at 10.

66.Bailey-Harris, Davis, Barron and Peara, above n 36 at 33. 
In his recent article Dewar argues that the 'chaos' inherent in legislation about the family 'is not a threat to the functioning of family law, because it is held at bay by the practices of legal and other professionals associated with its day-to-day interpretation, application and administration' ${ }^{67}$ I want to bring together this insight with the image of the 'trying-to-begood' family lawyer, by looking at the responses of the solicitors in the Brunel sample to questions about parental responsibility. I also want to do this bearing in mind the theoretical approach that Michael King and I have taken to the question of whether it is possible for legal communications and other types of communications to operate on conjunction with one another. ${ }^{68}$ What this means, according to King, is that the observer should be alert to the possibility that practitioners may be adept at switching from one discourse to another:

'While it might well be correct to state that law and the science of child welfare or justice and welfare cannot be merged into one super discourse, there is nothing to prevent lawyers or judges, as individuals, moving from one discourse to another and back again in their communications, whether these be decisions in legal proceedings or advice to clients. They cannot, however, communicate in both systems simultaneously, but may be able to do so sequentially in a way that gives the appearance of coherence ... . 69

\section{Parental responsibility}

The background to the questions asked of solicitors was not only the pivotal role played by

67. Dewar, above $\mathrm{n}$ at 485.

68. See M King and C Piper, How the Law Thinks 2nd Edn. (Aldershot: Arena, 1995). 69.King, above n 58 . 
the concept of parental responsibility in the Children Act $1989^{70}$ but also the fact that the Legal Aid Board expects solicitors to talk to divorce clients about it. The first published version of Transaction Criteria ${ }^{71}$ dealing with family work in chapter 1 , and also the latest issue, ${ }^{72}$ asks whether the lawyer has explained the legal and practical significance of the concept of parental responsibility to new clients. All interviewees were asked how they did that. $^{73}$

Many of the solicitors said it was too difficult to explain parental responsibility. They used phrases like, 'it's really hard', 'it's quite a task', 'I have difficulties myself in coming to terms with the concept' and 'you tell me what parental responsibility is and I'll tell the client'. This is quite interesting. It is true that the Law Commission ${ }^{74}$ had decided that it was not practicable to provide a list in statute of factors relating to parental responsibility but, nevertheless, family law textbooks are quite able to provide relatively clear lists of legal duties, rights and authorities ${ }^{75}$ and case law - at least at the time of research - was clear about parental responsibility as a status. Their confusion stems from the fact that they were trying to convey a message that went beyond legal concepts. In

70. For example, one of the Law Commissioners - then Professor Hoggett, now Mrs Justice Hale - said that parental responsibility was 'the conceptual building block used throughout the [Act]' (B Hoggett 'The Children Bill: The Aim' 19 Family Law 217). 71. A Sherr, R Moorhead and A Paterson Transaction Criteria (Legal Aid Board, HMSO, 1992).

72. The Family Transaction Criteria, Issue 2 (the latest issue) includes two relevant questions in Part 4 (Residence and contact disputes): '144: Did the lawyer advise the client generally about parental responsibility? 145: ... did the lawyer advise the client on the likely practical significance of the continuing parental responsibility of both parents?' (Legal Aid Board, 1995, p 40). The wording of these particular criteria was the same in Issue 1.

73. The question in relation to the franchise criteria was 'Can you tell me briefly what sort of things you say?'.

74., Law Commission Family Law, Review of Child Law Guardianship and Custody Law Comm No. 172 (London: HMSO, 1988) para 2.6.

75. See, for example, P Bromley and N Lowe, Bromley's Family Law 8th ed. (London: Butterworths, 1992) at pp 301-317. 
analysing their responses, what became clear is that conveying a particular set of attitudes took priority over a strict reading of the legal substance of a section of the Act something we try to teach our students not to do.

Just under half of the solicitors (16) reiterated the ‘definition’ they gave to parents: their emphases differed but they all in effect summarised section 3 of the Act. Only one solicitor talked solely of rights, eight focused on telling clients that it was `rights and duties', 'rights and responsibilities' or 'rights and duties and obligations' and six were concerned to give clear priority to responsibility, defining the concept as `a bundle of responsibilities' or 'duties and obligations'. ${ }^{76}$ One solicitor replied, 'I tell them what the law says' (and, indeed, some of these definitions included the words of section 3) but this solicitor - and many others - did not stop there. He went on to explain, 'I don’t have one set approach - depends on what needs to be said'. For some that meant conveying a particular idea about the parental responsibility of separating parents: 'I would ... try to emphasise to the clients that it is their responsibility to do what is in the interests of children'. Clearly this mirrors the inherent tension within the Act between the words of section 3 which relate to existing parental rights and the intention of the Law Commission to convey a message that rights exist solely to further the child's welfare. The new concept of parental responsibility was crucial, as Hoggett pointed out, 'To emphasise the practical reality that bringing up children is a serious responsibility rather than a matter of legal rights'. ${ }^{77}$

This tension is very apparent also in the comments of the remaining solicitors those who had not given a definition but talked about parental responsibility. They drew to

76. The remaining solicitor defined the concept in relation to what it was not, that is 'the old custody'.

77.Hoggett, above $\mathrm{n} 70$ at 217. 
the attention of clients one or more of four aspects of parental responsibility phased in the following terms: the continuing nature of parental responsibility, the equality of rights and responsibilities as between parents, its giving of involvement in parenting and its importance in relation to major decisions. ${ }^{78}$ Those solicitors who stressed that both parents had or shared the same or equal rights and duties, or 'legal footing', and talked in terms of 'retaining' rights and duties `for ever"79 ${ }^{79}$ could be seen as summarising sections 2(1) and 2(6) of the Children Act 1989 (though `equal’ is not the same as `each'). However, statements that parents would `continue to be parents' after divorce, `so that they know they are there for life' and that divorce 'makes not the slightest difference to your responsibility to the child' are doing something other, ${ }^{80}$ as were the comments about ‘involvement'.

Almost half the solicitors told clients that parental responsibility ensured 'involvement' in parenting or 'sharing in' the 'child's life ${ }^{\text {, }}$ but they often did not specify what they meant or they used language to which clients could give their own 'everyday' meanings. Many fudged the distinction between practical involvement in care-giving and rights to make decisions or ask the court to adjudicate by moving sequentially between legal and everyday meanings. For example one solicitor said she told non-residential

78. Except for one interview where time was at a premium, all solicitors who had stated a definition went on to focus on one or more of these aspects. Of the remaining solicitors all but three (one who was somewhat confused by the question and two who said they did not explain parental responsibility to married couples) concentrated without preamble on one or more of these aspects.

79. Eleven and ten solicitors respectively (16 solicitors in total) said they drew the equal (as between parents) and continuing (after divorce) aspects to the attention of divorcing parents.

80. In legal terms parentage is not the same as parental responsibility and parental responsibility does not last for the life of parent or child (except in the case where the parent or child dies before the child reaches its majority).

81. Only five solicitors appeared to used the word 'involvement' solely and specifically in the context of making decisions or 'action on important matters'. 
fathers that they `are still involved to a great extent in the children's upbringing' but immediately followed this by a list of the rights to make specific decisions. Others made comments like the following: `both parents should grasp [parental responsibility] so that they know ... they're sharing in this child's life', '[I] tell fathers it gives them rights to be involved in the child's life and decisions' and '[parental responsibility is] all the rights and duties that they have as parents from a practical point of view ... for instance, .. the ability to have copies of school reports'. ${ }^{82}$

\section{Motivating clients}

These solicitors mix legal and non-legal statements and use, sequentially, but without explanation, words which are to be found in social, welfare and legal discourses with different meanings. They do this to create the motivation they require in parents. Yet some solicitors were not happy with their own rhetoric. As one solicitor commented after he had finished explaining what he said to parents:

'If you want to be cynical about it, the father who has parental responsibility and sees the child for staying contact every other weekend, might in actual fact not be exercising parental responsibility at all, in that the mother decides where they go to school, where they get christened, everything'.

82. Three more gave examples of, respectively, receiving school reports, ‘having information' and 'getting to parents evenings' but as part of a list which includes decisions about medical treatment, the child's schooling, taking the child abroad and 
consent to marriage. 
Solicitors sometimes saw this as the 'truth' that they could only tell to some clients. An example given was when a mother needed reassuring that parental responsibility would not let the father 'interfere too much'. Three solicitors, however, took their dilemma to a different resolution: they told parents that, `what matters is what you do ... it doesn't really matter what the legal labels are' because 'in practice parental responsibility means nothing' and 'is only as effective as you make it between the two of you'. One solicitor specified what the practice might be for non-residential fathers: 'If you turn up for contact and remember their birthdays and Christmas, take them on holiday, then that's what matters ... it does involve a considerable amount of emotional energy and time to make it work'.

Where the client was a non-residential father the explanation was tailored depending on whether he was perceived as a potential nuisance or not. So, a restricted idea of involvement was alluded to in the comments of nine solicitors who said they tell those clients who were, or would be, the `absent parent’ that the caretaking parent always makes all the 'normal everyday decisions'. Their imaginary talk to parents therefore included statements such as, 'it's not a charter to ring up mum every five minutes' and 'it doesn't mean [you] can tell her what sort of breakfast cereal the child has'. If the solicitor thinks the client will be a 'sensible' absent parent then the talk is in a wider non-legal language which seems to offer more.

Many solicitors made one or more comments referring to the decision-making aspect of parental responsibility. Of these, some ${ }^{83}$ solicitors told clients that parental responsibility gave them the right to make major decisions, often specifying what counted

83. 12 out of the 23 solicitors referring to decision-making. 
as major decisions, whilst some ${ }^{84}$ used the phrase `you've both got a say' or explicitly told parents they must consult with each other before making major decisions. ${ }^{85}$ Three of the solicitors also focused on the right to make applications to court when there was no agreement over particular issues. Again, however, these legal statements are juxtaposed with something other.

'I try to define parental responsibility ... it being a recognition of being a parent ... it's not open to one parent to make decisions unilaterally. But basically to convey the impression that they are both still involved and they can't take, or shouldn't take, unilateral action on important matters. There should be as much discussion and conferring as is possible.' [Emphases added.]

Solicitors tailored their explanations of parental responsibility with the aim of reducing conflict between the client and the other parent and of promoting what is deemed as the best interests of the child - that is the involvement of both parents in that child's life. This meant that not only might the aims of reducing parental conflict and promoting contact conflict but the words of the Act might conflict with what they perceived was the desired message.

\section{VI 'ON MESSAGE'}

What emerges from these research studies is that family solicitors acting as matrimonial child specialists are engaged largely in an exercise to create and transfer particular values

84. Two of these solicitors and a further 11 .

85. A 'fact' backed by case law but not the Act itself. See also M McLean and J Eekelaar The Parental Obligation (Oxford: Hart Publishing, 1997). 
to the soon to be separated-but-continuing family. ${ }^{86}$ Many of the solicitors' comments sounded familiar: they echoed the language of the professional and government documents issued at the time of the passage and implementation of the Children Act. The policy aim was to use a change of nomenclature to signify a different role for law in regulating the family and to convey a particular message. ${ }^{87}$

One of the major mechanisms for educating professionals into internalising this policy shift were the many volumes of guidance which accompanied the Children Act 1989. One such, the Department of Health's Introduction to the Children Act 1989 shows how the Children Act was 'marketed' as more than a legal document:

'In private law proceedings ... The orders available under the Act look to practicalities rather than legal rights. ... The Act rests on the belief that children are best looked after within the family with both parents playing a full part.' [Emphasis added] ${ }^{88}$

86. What I previously wrote about mediators could now apply to the family law specialist. To summarise: they endorse particular client problems and not others, they construct particular suggested arrangements as 'good' and not others, they refer to particular types of solutions as 'the real solution' and they do all this through a particular construction of parental responsibility: see C Piper The Responsible Parent (Hemel Hempstead: Harvester Wheatsheaf, 1993).

87.J Eekelaar 'A Jurisdiction in Search of a Mission: Family Proceedings in England and Wales’ (1994) 57(6) Modern Law Review 839-858.

88. Department of Health, 1989, paras 1.28 and 1.3. 
The Circular issued by the Home Office to the Probation Service repeated the second sentence quoted above from the Introduction, noting in relation to section 8 orders, 'These orders focus on the child's interests so as to resolve specific areas of dispute rather than allocating legal rights and are designed to encourage parents to maintain their involvement in the child's life' ${ }^{89}$ National Family Mediation in its own publication about the Act stated, 'In contrast [to parental rights] parental responsibility gives significance to the everyday practical responsibilities of caring for children, ${ }^{90}$ and the Children Act Advisory Committee, in stating the five principles of the Act, included the following comment on continuing parental responsibility: 'children are best cared for by both parents wherever possible’ [emphasis added]. ${ }^{91}$

The legal provisions relevant to separation and divorce have, therefore, consistently been presented as more novel and more significant than the words of the legislation merit. As A Conciliators Guide to the Children Act 1989 began, 'The Children Act 1989 represents a radical new approach to the management of family disputes'. ${ }^{92}$ The SFLA in its 'Children Act Special' Newsletter similarly stated: 'The Act is based on an entirely new approach. For example, ... Parents who live separately from their children will be encouraged to remain actively involved in their upbringing' ${ }^{93}$ One contributor pointed to the 'heavy duty on practitioners to emphasise to their clients the importance of 'responsibility' rather than 'rights' in relation to children ... The task is likely to be

89. Circular 65/1991, at paras 3 and 10 respectively.

90. A Conciliators Guide to the Children Act 1989 (undated) at p 2. National Family Mediation (then the NFCC) is the umbrella organisation for independent out-of-court mediation services which is now part of the UK College of Mediators.

91.Above $n 9$ (1992) at 4.

92. Above $\mathrm{n} 90$ at $\mathrm{p} 1$. This text also argued that conciliators are crucial because they 'orchestrate a process that enables parents undergoing separation and divorce to realise in practice the principle of parental responsibility in relation to their children' (at p 1).

93. 1991 at p. 157. 
increasingly important so as to try to encourage clients ... to approach the question of arrangements ... in the frame of mind the Act is intended to encourage' ${ }^{94}$

94. Above n 93 at 163. 
As we have been made aware, family law potentially has within it conflicting ideologies of seeking the greater good of families and of individual justice and selfinterest; ${ }^{95}$ there is a tension between utility and rights functions. ${ }^{96}$ It would seem that family lawyers have internalised the family policy trend of the 1980s outlined by Eekelaar:

‘The removal of children’s appointments was but one illustration of a widespread process characteristic of family law policy in the 1980s: the gradual withdrawal of the legal protection of and support for people living in families. Henceforth family members were to be encouraged to exercise individual responsibility towards each other. ${ }^{, 97}$

The 'good' family lawyer, following the lead of the Law Commission, governmental guidance on the Children Act 1989 and their own continuing professional training, uses a language of involvement and responsibility - concepts which have taken on particular meanings when used by those 'good' solicitors who feel no professional discomfort. They have reconstructed the political and social meanings of these terms for use in a legal discourse. 'Involvement' in an everyday sense where practical `doing' would be indicated is not what most solicitors mean. Indeed, if parents had indicated they had disputes over the 'real' practicalities of continuing parenting - laundry, taking the child to medical appointments during working hours, sending or taking food and other items to school at the appropriate time - then they would have been labelled as childish. The law is not concerned with such trifles and nor are specialist family lawyers though their use of hybrid

95. Walker above $\mathrm{n} 26$ at 5.

96. See Dewar, above $n 2$ at 470-2. 
terms often gives the impression that they are.

97. Above n 87 at p 404. 
The traditional socio-legal approach to lawyering which analyses how lawyers 'translate' the complex 'life' of their client into legal categories would seem redundant in an analysis of what specialist lawyers do most of the time in relation to children issues. The exercise is to convey social norms of behaviour for the divorcing client - norms that avoid the use of substantive law and discourage conflict. Judges deem as 'sensible' solicitors those who are able to do this. ${ }^{98}$

Not all our solicitors, however, were working within and thinking within these reconstructed meanings and, therefore, they experienced a disjuncture between what they knew they were `supposed’ to say and what they believed was the strictly legal position. For them, the words they were using were not really 'true' if taken at their everyday meanings. A small number commented about parental responsibility : 'What does it amount to? ... Is it much more than a consolation prize', 'whether they can exercise it is a different matter altogether' and `in real terms it doesn't mean a lot’.

VII SPECIALISTS OR SPIN DOCTORS?

98. Bailey-Harris et al, above n 36 . 
The tension apparent in the comments of solicitors is that between the spin doctor involved in helping those divorcing to move smoothly to separate households with as little intervention by the legal system as possible - and the lawyer who knows the letter of the law and the procedures to activate the duties and rights therein. ${ }^{99}$ Some solicitors understand they are conveying a message about what parents 'should' do and realise that the law as legal remedy can only be used sparingly in relation to parental responsibilities. The process of legitimation of those conflicts that can still be 'fought' without the professional losing specialist status by taking an adversarial approach ${ }^{100}$ is now very important. There is a self-denying ordinance not to 'talk law' but not all solicitors can 'manage' that either to their own satisfaction or to be internally consistent.

The confusions and mixed messages that transcripts of interview tapes with solicitors illuminate are the inevitable result of the fact that Acts of Parliament - whilst in legal language and tailored to fit in with the existing law of the realm - are basically texts stemming from political aims and objectives. The words of legislation may or may not accurately embody political imperatives and legislation may not be internally consistent but new legislation is sold to the professionals with the desired messages. According to Dewar this is deliberate:

'To put it another way, law more and more becomes the context in which those

99. The reference made by C McEwen, R Maiman and L Mather ('Lawyers, Mediation and the Management of Divorce Practice' (1994) 28(1) Law and Society Review 149186 ) to the balancing act' (that between giving legal advice and addressing non-law issues) 'at the heart of divorce lawyers work' can, on this basis, be critiqued as setting up a false dichotomy.

100. See C Smart The Ties that Bind: Law, Marriage and the Reproduction of Patriarchal Relations (London: Routledge and Kegan Paul, 1984) p 165. A current example could be judicial legitimation of solicitor representation of a child in private law proceedings in only a narrow range of circumstances: see, for example, $\operatorname{Re} S$ [1993] 2 
contradictions or oppositions that cannot be resolved politically are worked through. ... legislators have in fact created a set of inconsistent principles and commitments ... while at the same using law to give the appearance of having created shared values; and then have off-loaded the detailed working out of those contradictions to the legal system., ${ }^{101}$

So solicitors convey, selectively, the message or the possibilities for legal remedies, such that they retain control of cases and are perceived as specialist by their colleagues and the judiciary. They may, in that process, be reinforcing messages from the political and child welfare discourses though they are not always aware of this and, at times, may express scepticism over the messages.

The 'good' family lawyer is a specialist at moving between these discourses to control and motivate clients. But where does this leave family law and family law teachers? An obvious point to make is that most of this paper is a far cry from the spread and depth of family law jurisprudence that we find in the pages of the Family Law Reports and in academic journals. Even allowing for the fact that this article has concentrated largely on child-related lawyering, there is an increasing divergence between the 'law' of the practising family lawyer and that of the academic which is no longer explained by an emphasis by the latter on procedure.

FLR 437.

101. Dewar, above n 2 at 484 . 
A further point, one which Eekelaar has already made in the context of the contraction of the court's child protectionist role to exceptional cases, is that 'There is ... a danger that the relative marginalisation of the courts in family matters will lead to a belief that the law itself has only a marginal role to play. This could be a serious mistake'. ${ }^{102}$ Recent research on divorce solicitors with cases involving children would suggest that this mistake has already been made. Most cases are dealt with by successfully teaching clients and amalgam of political and welfare norms, either in the solicitor's office or on court premises. The use of law and litigation is now legitimated only in exceptional court applications.

102. Above n 87 at 858. 
Whether this conclusion can be extended to the situation when family specialists are dealing with money and property is not, however, clear. There has so far been an assumption that solicitors revert to being 'bad' when the children issues have been dealt with, ${ }^{103}$ but the comments of some of the solicitors in the Brunel research would suggest that this distinction is no longer so clear cut. Where there are dependent children in the family, money and property are sometimes presented as issues which divide the family and harm the children and are subject to the same dominant rhetoric. For example, one solicitor, when asked what information she routinely gave to new divorce clients replied,

'I remind parents ... that as parents they've got to continue to get together in their children's interests ... This is how I encourage people to settle their finances reasonably um - thinking about how the child should be looked after'.

103. Walker, for example, points out that solicitor acceptance of child focussed mediation could be seen as part of a 'deal' struck by mediators to gain support and that 'adversarial positioning' has continued in relation to money and property and, as a result, 'concepts such as fairness, justice and rights ... are referred to in relation to finance and property,' ( above n 26 at 55-7). See also, Davis et al above n 39. 
Cretney has recently drawn attention to the opinion of the specialist family lawyer held by the post-Second World War Attorney General, Sir Hartley Shawcross: 'Specialisation by the Divorce Bar has tended to give them a vested interest in what should be (and in truth is) a very simple branch of the law ... cases which take only two or three minutes and require no study or thought at all. ${ }^{104}$ Cretney explained he had originally intended to discuss whether the role of the family lawyer was still 'something of a racket' in the dictionary sense of 'an easy and lucrative means of livelihood'; ${ }^{105}$ in other words, whether the 'specialism' is a professional construct invented out of self-interest and of little real legal substance. Certainly it is now a very complicated construct. Whether it is law is another matter. ${ }^{106}$

It may be that, as law teachers, we should be more involved in the business of deconstructing legislation than at present so that the specialist practitioner comes to understand better the nature of what he or she is doing when imparting these messages to clients. I suggest this because the discourses which underpin the Family Law Act 1996 are particularly questionable. ${ }^{107}$ They present seemingly consensual understandings about the nature of marriage, parenting, domestic violence, the effects of divorce on children, and so on. Yet, these understandings, which form the basis for those non-law norms which

104. Quoted in S Cretney 'Family Law - “A Bit of a Racket”?' (1996) NLJ Practitioner Jan 26, 91-95 at p 91.

105. Above $n 104$ at p 91.

106. I realise this is hardly a novel conclusion. Katherine O’Donovan started a chapter on 'Family Law and Legal Theory' with 'The view that family law is not really law seems to be gaining credence’ (in W Twining (ed) Legal Theory and Common Law (Oxford: Blackwell, 1986).

107. Hopefully, this process of questioning has already begun. A recent seminar organised by the National Council for family proceedings was entitled 'Assumptions and Presumptions in Family Justice Thinking’ (Tavistock Centre, London, 9 December 1998). 
solicitors help to convey, are often not (fully) supported by empirical research studies. ${ }^{108}$ Good family lawyers should re-examine these norms or risk colluding with the government to write legal norms, remedies and rights out of the script.

108. See, for example, S Day Sclater and C Piper (eds) Undercurrents of Divorce (Aldershot: Ashgate, 1999). 